УДК: 636.4: 619: 615: 619: 616.34-002

(C) 2015

Шатохін П. П., Супруненко К. В., кандидати ветеринарних наук, Каришева Л. П., старший викладач

Полтавська державна аграрна академія

\title{
ФАРМАКОТЕРАПЕВТИЧНА ЕФЕКТИВНІСТЬ ПЕРИТОЛУ ТА ВОДОРОЗЧИННОГО АСПІРИНУ У ЛІКУВАННІ ПОРОСЯТ, ХВОРИХ НА ГАСТРОЕНТЕРИТ
}

\section{Рецензент - доктор ветеринарних наук, професор Б. П. Киричко}

Розглянуто питання лікування поросят відлучного віку хворих на гастроентерит. Метою нашого дослідження було застосування в комплексному лікуванні хворих поросят препаратів, а саме: антагоніста серотоніну - перитолу та препарату з групи саліиилатів - водорозчинну форму ацетилсаліцчилової кислоти [15]. Встановлено, щцо препарати, які ми застосовували, виявляють різнобічну дію на організм поросят, зокрема на показники еритропоезу, деякі показники антиоксидантної системи та концентраиію тіреоїдних гормонів. За результатами дослідів визначено терапевтичну ефективність запропонованих нами схем лікування.

Ключові слова: поросята, гастроентерит, перитол, водорозчина форма ацетилсалічилової кислоти (ВФАСК), ивидкість осідання еритроцитів (ШОЕ), вміст гемоглобіну, кількість еритроцитів, величина гематокриту, трийодтиронін $\left(T_{3}\right.$, кортизол), тетрайодтиронін $\left(T_{4}\right.$, тироксин), перекисна резистентність еритрочитів (ПРЕ), малоновий діальдегід (МДА).

Постановка проблеми. До основних причин виникнення первинного гастроентериту належить ціла низка факторів аліментарного або ендогенного походження, зокрема вплив стресфакторів на організм тварин, особливо в разі промислової технології вирощування. Патологічний процес супроводжується порушенням порожнинного та мембранного травлення, посиленням моторної і секреторної функції, що обумовлює виникнення діареї, зневоднення організму, втрату великої кількості білка й електролітів.

Важливу роль у патогенезі розвитку вищеназваних патологій відіграють тканинні гормони гістамін, серотонін, брадікінін, простагландін та інші.

Тому, на нашу думку, включення до схеми комплексного лікування поросят, хворих на гастроентерит, перитолу (інгібітора серотоніну) та ВФАСК (блокатора простогландін-Н-синтетази) має полегшувати перебіг хвороби та підвищувати фармакотерапевтичну ефективність лікування.
Аналіз основних досліджень і публікацій, у яких започатковано розв'язання проблеми. Шлунково-кишкові захворювання молодняку свиней досить часто реєструються особливо в умовах промислових комплексів. Економічні збитки від даної патології складаються зі втрат приросту маси тіла молодняку та їх загибелі, витрат на лікування, ослаблення резистентності тварин та підвищення сприятливості до інших хвороб $[2,12,17]$.

Унаслідок переходу тваринництва, зокрема галузі свинарства, на промислову основу відбуваються певні зміни в умовах годівлі та утримання $[2,11,12,16]$. 3 одного боку, сучасні умови ведення тваринництва сприяють значному збільшенню виробництва продукції тваринного походження, але під впливом нових технологій годівлі, адинамії, великої скупченості поголів'я та порушення обміну речовин з'являються нові фактори впливу на патогенез хвороби, змінюється класичний перебіг патологій, знижується фармакотерапевтична ефективність методів лікування хворих тварин [16].

Останнім часом все більше уваги приділяється синдрому ендогенної інтоксикації, як ведучій ланці у патогенезі багатьох захворювань. Встановлено тісний взаємозв'язок між інтенсивністю розвитку синдрому ендогенної інтоксикації та активацією процесів пероксидного окиснення ліпідів (ПОЛ). Як наслідок, поряд з активацією мембранних фосфоліпаз відбувається дестабілізація клітинних мембран шляхом перебудови їх ліпідного бішару $[5,20]$. Стан клітинних мембран відображає ступінь ендотоксикозу - як показник сумарного впливу усіх мембраноруйнуючих факторів на клітину, тому порушення структури і функції мембрани обумовлює всі інші патоморфологічні та клінічні прояви єндотоксикозу $[5,17,19]$.

У роботах багатьох авторів встановлена тісна кореляція між змінами властивостей мембран еритроцитів та клітинних мембран внутрішніх органів. Контактуючи 3 усіма тканинами і всту- 


\section{ВЕТЕРИНАРНА МЕДИЦИНА}

паючи з ними у морфофункціональні взаємовідносини, еритроцити є відображенням фізіологічних та патологічних змін, які відбуваються в організмі [13].

Зміни активності мембранних ферментів, каналів та рецепторних білків, викликаних несприятливими факторами, посилюють активність вільнорадикального окиснення ліпідів (ВОЛ), що відіграє вагому роль у патогенезі багатьох хвороб, зокрема гастроентеритів. Процес пероксидації ліпідів відбувається за безпосередньої участі вільних радикалів. Вільні радикали (ВР) - це молекулярні частинки, які мають непарний електрон на зовнішній орбіті і володіють високою реакційною здатністю. Збільшення кількості ВР викликає посилення процесів пероксидного окиснення ліпідів (ПОЛ) (іноді це називають «оксидантним стресом»), що супроводжується низкою порушень властивостей біологічних мембран та функціональної активності клітин [10].

Попереджувальну функцію руйнуючої діï ВР на клітини виконує антиоксидантна система (AОC), яка підтримує прооксидантно-антиоксидантну рівновагу, що є важливою ланкою у підтриманні гомеостазу $[12,18]$.

У здоровому організмі процеси ПОЛ відбуваються на низькому рівні, тому накопичення його токсичних продуктів виключено. Однак через інтенсивний та довготривалий вплив на організм подразнюючих факторів різного походження процес ПОЛ стає ведучою ланкою у патогенезі багатьох захворювань [16].

На чисельних моделях експериментальних виразок шлунку встановлено безпосередню участь у патогенезі ульцерогенезу біологічного аміну серотоніну $[1,7,20]$. Серотонінова система відіграє велику роль у життєдіяльності організму і регулює нервову діяльність, функцію ендокринних залоз, зокрема вісь гіпоталамус - гіпофіз кора наднирників, а також регулює діяльність органів травлення. Вплив на організм алергічної сенсибілізації викликає дегрануляцію лаброцитів iз вивільненням серотоніну, який викликає спазм судин стінки шлунку, порушує трофіку, різко знижує бар'єрну функцію слизової оболонки шлунка, i, як наслідок, відбувається їі самоперетравлювання [6].

Експериментальними дослідженнями на щурах 3 використанням моделі штучного ульцерогенезу встановлено, що шестиразове підшкірне введення людської сироватки, адьюванта Фрейнда, голодування та іммобілізації викликає утворення ерозій та виразок у шлунку, в патогенезі розвитку яких певну роль відіграє серотонін. Введення антагоніста серотоніну - перитолу галь- мувало процес ульцерогенезу, а ВФАСК - зменшувала кількість ерозій і виразок.

У дослідах по вивченню антиексудативних властивостей ВФАСК на моделі набряку кінцівки у щурів за субплантарного введення 0,1 мл $0,02 \%$ розчину серотоніну встановлено, що препарат зменшує дію ендогенного серотоніну в залежності від дози: чим вище доза ВФАСК, тим менше об'єм набряку [20].

Мета дослідження - дослідити фармакотерапевтичну ефективність перитолу та ВФАСК у комплексному лікуванні поросят відлученого віку, хворих на гастроентерит. Для досягнення цієї мети були поставлені такі завдання:

- сформувати три дослідні групи поросят, хворих на гастроентерит, і провести лікування згідно $з$ розробленими схемами;

- визначити та проаналізувати показники еритропоезу в крові поросят, деякі показники антиоксидантної системи та концентрацію тіреоідних гормонів до проведення досліду та на 7-му добу досліджень;

- визначити збереженість поросят у всіх дослідних групах.

Матеріали та методи досліджень. Експериментальні дослідження проводили в умовах наукової лабораторії кафедри терапії Полтавської державної аграрної академії. Об'єктом дослідження слугували поросята відлучного віку ДПНДГ «Ювілейне» Полтавського району Полтавської області.

Для проведення експерименту були сформовані, за принципом аналогів, три групи поросят відлучного віку, в яких на другу добу після переведення $з$ маточного цеху до цеху дорощування спостерігали ознаки порушення функції шлунково-кишкового тракту.

Лікування поросят, хворих на гастроентерит, проводили за наступною схемою:

- перша дослідна група (50 голів) - внутрішньом'язово вводили $0,3 \%$ розчин водорозчинної форми ацетилсаліцилової кислоти 3 розрахунку 3 мг/кг один раз на добу, 7 діб поспіль. Одночасно внутрішньом'язово вводили 5 мл вітамінної суміші (риб'ячий жир з тривітом у рівних пропорціях), 1 раз на добу, двічі 3 інтервалом у 5 діб. Замість води випоювали відвар кори дуба;

- друга дослідна група (46 голів) - внутрішньо таблетки перитолу з розрахунку 8 мг/гол (2 таблетки) 1 раз на добу, 7 діб поспіль, вітамінну суміш та відвар кори дуба за загальною схемою;

- третя дослідна група (48 голів) - одночасно застосовували ВФАСК і перитол, вітамінну суміш та відвар кори дуба у вище зазначених дозах.

Для проведення гематологічних досліджень у 


\section{ВЕТЕРИНАРНА МЕДИЦИНА}

піддослідних поросят проводили відбір проб крові з передньої порожнистої вени (в кількості сім проб з кожної групи) двічі - у перший день досліду та на 7-му добу досліджень.

У стабілізованих «Трилоном Б» пробах крові визначали: швидкість осідання еритроцитів за методом Панченкова, вміст гемоглобіну - уніфікованим геміглобінціанідним методом, кількість еритроцитів - пробірковим методом П'ятницького (Николаєва) у сітці камери Горяєва, величини гематокриту методом мікроцентрифугування за Шкляром [3]. Перекисну резистентність еритроцитів у крові визначали за методикою Iager H. С. [25] та кількість малонового діальдегіду тестом 3 тіобарбітуровою кислотою (4). Вміст тетрайодтироніну і трийодтироніну на автоматичному імунохемілюмінісцентному аналізаторі [26]. За станом перебігу хвороби у дослідних поросят проводили постійний контроль.

Результати досліджень. Результати досліджень середньої величини ШОЕ у крові хворих на гастроентерит поросят усіх дослідних груп свідчать, що даний показник знаходиться в межах фізіологічної норми за незначного коливання між групами ( $\operatorname{Lim} 3,9-4,0$ мм/год). Дані показника ШОЕ на 7-му добу досліджень дають змогу стверджувати про зменшення його середньої величини в крові поросят усіх дослідних груп (табл. 1).

У першій дослідній групі показник ШОЕ до початку лікування дорівнював 4,0土0,7 мм/год а

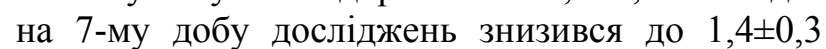
мм/год $(\mathrm{p}<0,05)$. Аналогічні зміни даного показника відбуваються у другій та третій дослідних

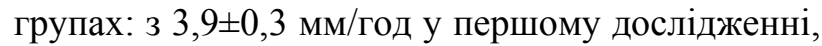
до 2,3 $\pm 0,4$ мм/год $(\mathrm{p}<0,05)-$ у другому, з 3,9 $\pm 0,2$ мм/год, до 1,6 $\pm 0,2$ мм/год $(\mathrm{p}<0,01)$ - в третій дослідній групі відповідно. Водночас слід підкреслити, що в 1-й і 3-й дослідних групах для комплексного лікування поросят, хворих на гастроентерит, застосовували ВФАСК, зменшення середньої величини показника ШОЕ було нижче по відношенню до такого у другій дослідній групі на 39 та на 31 \% - у 3-й дослідній групі.

Величина показника вмісту гемоглобіну в крові поросят хворих на гастроентерит першій та третій дослідних групах знаходилась у межах фізіологічної норми ( $\operatorname{Lim} 10,7-11,5$ \%), а в другій групі збільшення даного показника становить 7 \% по відношенню до верхньої межі фізіологічної норми. На 7-му добу досліджень у першій дослідній групі показник вмісту гемоглобіну збільшився на 11 \% по відношенню до показника першого дослідження та на 7 \% - по відношенню до меж фізіологічної норми. У другій дослідній групі відбувається зниження даного показника 3 $12,7 \pm 0,6 \%$ до $10,6 \pm 0,3 \%$ (p $<0,05)$, у третій до-

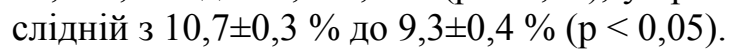

Показник гематокритної величини у першому дослідженні в крові поросят усіх дослідних груп не досягав нижньої межі фізіологічної норми. У 1-й і 2-й дослідних групах він був у межах $5 \%$ та на $15 \%$ - по третій. На 7-му добу досліду по перший дослідній групі спостерігається тенденція до зниження даного показника по відношенню до попереднього, а по 2-й і 3-й відбувається зменшення показника гематокритної величини відповідно з 37,6 $\pm 1,9 \%$ до $31,4 \pm 1,4 \%(\mathrm{p}<0,05)$ та $333,1 \pm 1,3 \%$ до $26,6 \pm 0,3 \%(\mathrm{p}<0,01)$.

Кількість еритроцитів у крові поросят, хворих на гастроентерит, усіх дослідних груп була без значних коливань ( $\operatorname{Lim} 3,3-3,5$ Т/л), але нижче меж фізіологічної норми відповідно на $45 \%$ - у $1-и ̆, 43 \%$ - у 2-й та $42 \%$ - у 3-й дослідній групі.

У другому дослідженні по 1-й дослідній групі спостерігається тенденція до зниження кількості еритроцитів до $6 \mathrm{~T} /$ л.

\section{1. Показники еритропоезу на 1-шу та 7-му добу досліджень}

\begin{tabular}{|c|c|c|c|c|c|c|c|c|c|}
\hline \multirow{2}{*}{ Групи } & $\mathrm{n}$ & \multicolumn{2}{|c|}{ ШОЕ, мм/год } & \multicolumn{2}{|c|}{ Гемоглобін, \% } & \multicolumn{2}{|c|}{ Гематокрит, \% } & \multicolumn{2}{c|}{ Еритроцити, Т/л } \\
\cline { 2 - 9 } & 1 доба & 7 доба & 1 доба & 7 доба & 1 доба & 7 доба & 1 доба & 7 доба \\
\hline $\begin{array}{c}\text { I до- } \\
\text { слідна }\end{array}$ & 7 & $4,0 \pm 0,7$ & $\begin{array}{r}1,4 \pm 0,3 \\
*\end{array}$ & $11,5 \pm 0,8$ & $12,8 \pm 0,5$ & $37,7 \pm 1,4$ & $36,3 \pm 1,0$ & $3,3 \pm 0,3$ & $3,1 \pm 0,3$ \\
\hline $\begin{array}{c}\text { II до- } \\
\text { слідна }\end{array}$ & 7 & $3,9 \pm 0,3$ & $\begin{array}{c}2,3 \pm 0,4 \\
*\end{array}$ & $12,7 \pm 0,6$ & $\begin{array}{c}10,6 \pm 0,3 \\
*\end{array}$ & $37,6 \pm 1,9$ & $\begin{array}{c}31,4 \pm 1,4 \\
*\end{array}$ & $3,4 \pm 0,3$ & $\begin{array}{c}5,0 \pm 0,2 \\
* *\end{array}$ \\
\hline $\begin{array}{l}\text { III до- } \\
\text { слідна }\end{array}$ & 7 & $3,9 \pm 0,2$ & $1,6 \pm 0,2 * *$ & $10,7 \pm 0,3$ & $9,3 \pm 0,4 *$ & $33,1 \pm 1,3$ & $\begin{array}{c}26,6 \pm 0,3 \\
* *\end{array}$ & $3,5 \pm 0,5$ & $\begin{array}{c}4,8 \pm 0,2 \\
*\end{array}$ \\
\hline
\end{tabular}

Примітка: * $-\mathrm{p}<0,05 ; * *-\mathrm{p}<0,01$, порівняно 3 попереднім періодом 
BETЕРИНАРНА МЕДИЦИНА

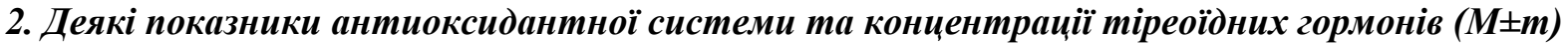

\begin{tabular}{|c|c|c|c|c|c|c|c|c|c|}
\hline \multirow[t]{2}{*}{ Групи } & \multirow[t]{2}{*}{$\mathrm{n}$} & \multicolumn{2}{|c|}{ ПРЕ, \% } & \multicolumn{2}{|c|}{ МДА, нМ/мл } & \multicolumn{2}{|c|}{$\begin{array}{c}\text { Трийодтиронін, } \\
\text { мг/мл }\end{array}$} & \multicolumn{2}{|c|}{$\begin{array}{c}\text { Тетрайодтиронін, } \\
\text { мг/мл }\end{array}$} \\
\hline & & 1 доба & 7 доба & 1 доба & 7 доба & 1 доба & 7 доба & 1 доба & 7 доба \\
\hline $\begin{array}{l}\text { I до- } \\
\text { слідна }\end{array}$ & 7 & $48,7 \pm 1,3$ & $48,4 \pm 0,6$ & $4,3 \pm 0,2$ & $\begin{array}{l}3,6 \pm 0,3 \\
* *\end{array}$ & $\begin{array}{c}321,0 \pm \\
39,9\end{array}$ & $\begin{array}{c}193,0 \pm \\
19,6 \\
*\end{array}$ & $55,6 \pm 4,1$ & $65,5 \pm 1,9 *$ \\
\hline $\begin{array}{l}\text { II до- } \\
\text { слідна }\end{array}$ & 7 & $48,4 \pm 3,7$ & $\begin{array}{l}65,1 \pm 2,3 \\
* *\end{array}$ & $3,3 \pm 0,1$ & $\begin{array}{l}3,9 \pm 0,1 \\
\quad * *\end{array}$ & $\begin{array}{c}313,0 \pm \\
31,8\end{array}$ & $\begin{array}{c}146,2 \pm \\
39,6 \\
*\end{array}$ & $56,7 \pm 4,0$ & $62,0 \pm 2,2$ \\
\hline $\begin{array}{l}\text { III до- } \\
\text { слідна }\end{array}$ & 7 & $47,4 \pm 4,8$ & $62,7 \pm 3,2 * *$ & $4,0 \pm 0,2$ & $\begin{array}{l}3,5 \pm 0,1 \\
\quad *\end{array}$ & $\begin{array}{c}338,6 \pm \\
70,6\end{array}$ & $\begin{array}{c}142,9 \pm \\
20,7 \\
*\end{array}$ & $52,7 \pm 5,3$ & $42,6 \pm 4,7$ \\
\hline
\end{tabular}

Примітка: ${ }^{*}-\mathrm{p}<0,05 ; * *-\mathrm{p}<0,01, * * *-\mathrm{p}<0,001$

\section{3. Збереженість поросят дослідних груп}

\begin{tabular}{|c|c|c|c|c|}
\hline Групи & Кількість голів & Загинуло (гол.) & Одужало (гол.) & Збереженість (\%) \\
\hline I дослідна & 50 & 7 & 43 & 86,5 \\
\hline II дослідна & 46 & 6 & 40 & 87,0 \\
\hline III дослідна & 48 & 4 & 44 & 91,7 \\
\hline
\end{tabular}

У 2-й та 3-й дослідних групах, навпаки, відбувається збільшення їх кількості. Так, у першій дослідній групі даний показник у першому дослідженні становив $3,4 \pm 0,3 \mathrm{~T} /$ л, а в другому $5,0 \pm 0,2$ Т/л, $(\mathrm{p}<0,01)$, по третій дослідній відпо-

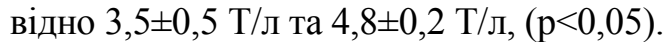

При визначенні показника середнього вмісту гемоглобіну в одному еритроциті встановлено що в 1-й групі на початку досліду він становив 3,5, а в другому дослідженні 4,1, по 2-й і 3-й дослідних групах відповідно: 3,7 проти 2,1 - у другій, та 3,1 проти 1,9 - у третій.

Відсоток перекисного окислення ліпідів у перший дослідній групі знаходився в 1-му та 2-му дослідженнях на одному рівні ( $\operatorname{Lim} 48,7-48,4$ \%). По 2-й та 3-й дослідних групах відсоток перекисного гемолізу еритроцитів у пробах крові дослідних поросят збільшується $3 \quad 48,4 \pm 3,7 \%$ до $65,1 \pm 2,3 \% \quad(\mathrm{p}<0,01) \quad$ та $3 \quad 47,4 \pm 4,8 \%$ до $62,7 \pm 3,2 \%$ ( $<0,01)$ відповідно (табл. 2$)$.

Кількість малонового діальдегіду - кінцевого продукту пероксидного окиснення ліпідів у сироватці хворих на гастроентерит поросят коливався від 3,3 до 4,3 нМ/мл. У першій дослідній групі на початку досліду кількість МДА становила 4,3 $\pm 0,2$ нМ/мл, а на 7-му добу кількість його знизилась до $3,6 \pm 0,3$ нM/мл $(\mathrm{p}<0,01)$. Зменшення кількості МДА в сироватці крові відбувається в 3-й дослідній групі: 4,0土0,2 нМ/мл у 1-му та $3,5 \pm 0,1$ нM/мл $(\mathrm{p}<0,05)$ - у другому дослідженнях.

Концентрація трийодтироніну в сироватці крові поросят, хворих на гастроентерит, колива-

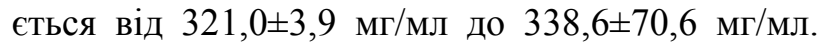
Результати другого дослідження, проведеного на 7-му добу досліду, свідчать про зниження вмісту кортизолу в сироватці крові. Так, у 1-й дослідній групі на початку досліду концентрація $\mathrm{T}_{3}$ в сироватці крові становив $321,0 \pm 3,9$ мг/мл, а на 7-му

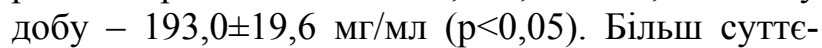
вим було зменшення концентрації $\mathrm{T}_{3}$ у 2-й та 3-й дослідних групах відповідно з 313,0 31,9 мг/мл до $140,2 \pm 39,6$ мг/мл $(\mathrm{p}<0,05)$ та $3338,6 \pm 70,6$ мг/мл до $142,9 \pm 20,4$ мг/мл $(\mathrm{p}<0,05)$.

Концентрація тетрайодтироніну в сироватці крові поросят за гастроентериту на початку лікування коливалось у межах $52,7 \pm 5,3-56,7 \pm 4,0$ мг/мл. У другому дослідженні вміст тироксину у сироватці крові в другій та третій дослідних групах збільшився відповідно на 17 і $9 \%$. У третій дослідній групі даний показник, навпаки, зменшився на $19 \%$.

Дані таблиці про збереженість поросят (табл. 3) свідчать, що в усіх 3-х дослідних групах під час проведення досліду зафіксовано загибель хворих на гастроентерит тварин. У першій дослідній групі з 50-ти поросят, у яких на початку досліду було встановлено діагноз на гастроентерит, за- 


\section{ВЕТЕРИНАРНА МЕДИЦИНА}

гинуло 7 голів і збереженість дорівнює 86,5 \%. Із 46 хворих поросят 2-ї дослідної групи загинуло 6 голів, збереженість становила $87 \%$. У третій дослідній групі із 46 голів хворих на гастроентерит поросят на 7-му добу досліду загинуло 4, збереженість дорівнює 91,7\%. Отже, збереженість по 3-й дослідній групі була вище на 5,2 \% по відношенню до 1-ої та на 4,7 \% - до 2-ої дослідної груп.

Аналіз показників еритрону дає змогу стверджувати, що в дослідних групах, де 3 лікувальною метою застосували ВФАСК показник середньої величини ШОЕ зменшується, що узгоджується 3 даними джерел літератури про мембраностабілізуючу дію аспірину шляхом інгібування простагландин-Н-синтетази [14, 21, 22].

Коливання показників гематокритної величини та кількості еритроцитів у дослідних тварин як на початку, так і в кінці досліду, відбувалися в межах нижче фізіологічних коливань. Можливо, це пов'язано 3 синдромом післявідлучного мультисистемного виснаження свиней (СПМВС) $[8,23]$.

Зниження кількості МДА та відсотка ПРЕ у крові поросят дослідних груп, яким у схемі лікування застосували ВФАСК, підтверджує дані джерел літератури про антиоксидантні властивості саліцилатів. Блокуючи синтез простагландинів, вони блокують ВОЛ, зменшуючи кількість вільних радикалів, і як наслідок, гальмується ПОЛ і підвищується активність антиоксидантної системи $[9,12,16,18]$.

Підвищення концентрації тироксину в сироватці крові поросят першої дослідної групи можна пояснити здатністю аспірину звільняти гормон від зв'язку з альбумінами $[24,26]$. Зменшення концентрації кортизолу в сироватці крові поросят

\section{БІБЛІОГРАФІЯ}

1. Белосточкий Н. И. Язвообразование в слизистой оболочке желудка крыс под влиянием катехоламинов / Н. И. Белостоцкий // Патол. физиолог. и эксп. терапия. - 1988. -№1. - С. 24-27.

2. Вержсихоський О. М. Профілактика метаболічних порушень у свиноматок і лікування поросят за диспепсії та гастроентериту : автореф. дис. на здобуття наук. ступеня к. вет. н. : 16.00.01/ О. М. Вержиховський - Київ, 2010. - 23 с.

3. Ветеринарна клінічна біохімія / [Левченко В. І., Влізло В. В., Кондрахін І. П. та ін.] ; за ред. В. І. Левченко і В. Л. Галяса. - Біла Церква, 2002. $-400 \mathrm{c}$.

4. Гаврилов В. Б. Анализ методов определения продуктов перикисного окисления липидов в сироватке крови по тесту с тиобарбитуровой кис- усіх дослідних груп у другому дослідженні, можливо, пов'язано з десенсибілізуючою та мембраностабілізуючою дією ВФАСК та перитолу [20, 26].

\section{Висновки:}

1. Комплексне лікування поросят відлученого віку, хворих на гастроентерит, з одночасним застосуванням перитолу і водорозчинної форми ацетилсаліцилової кислоти полегшує перебіг хвороби проявляючи багатобічну дію на організм та підвищує відсоток збереженості поросят.

2. Показник ШОЕ зменшується в усіх 3-х дослідних групах, оскільки усі введені препарати володіють протизапальними властивостями. Вміст гемоглобіну в 2-й і 3-й дослідних груп зменшується, а 1-й - збільшується на $11 \%$. Гематокритна величина була нижчою у другому дослідженні в усіх дослідних групах, відповідно, на 4,16 та 15 відсотків. Кількість еритроцитів у крові поросят 2-й і 3-й дослідних груп збільшується відповідно на 47 та $37 \%$, а в 1-й - зменшується на $6 \%$.

3. Відсоток перекисного гемолізу еритроцитів збільшується у 2-й і 3-й дослідних групах, а в 1-й - залишається незмінним. Кількість МДА в 1-й і 3-й дослідних групах знижується, до 3,6 нМ/мл

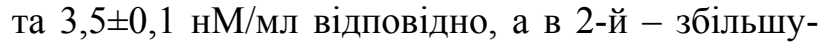
ється до $3,9 \pm 0,1 \mathrm{нM} /$ мл.

4. Концентрація кортизолу в сироватці крові у другому дослідженні знижується в усіх дослідних групах. Вміст тироксину в 1-й і 2-й дослідних групах збільшився відповідно на 18 та $9 \%$, в третій, навпаки, зменшення становило $19 \%$.

5. Введення в схему лікування хворим поросятам перитолу та ВФАСК підвищує збереженість поголів'я до 91,7 \%, що більше ніж така у 1-й і 2-й групах на 5,2 та 4,7 \% відповідно.

лотой / В. Б. Гаврилов, А. Р. Гаврилова, Л. М. Мажуль // Вопросы мед. химии. - 1987. - №1. C. $118-122$.

5. Газин И. К. Патофизиологические аспекты эндотоксикоза у больных сахарным диабетом, осложненным гнойной инфекцией стопы, и его коррекция при традиционном лечении и лечении с использованием озонированного физиологического раствора // Пат. физиол. и экспер. терапия. 2008. - №4. - C. 23-24.

6. Гройсман С. Д., Губкин В. А. О влиянии серотонина на желудочную секрецію, вызванную различными ее возбудителями / С. Д. Гройсман, В. А. Губкин // Физиол. журнал СССР. - 1989. 75. - №1. - С. 77-85. 


\section{ВЕТЕРИНАРНА МЕДИЦИНА}

7. Каревина Т. Г., Шевчук И. М. Влияние серотонина на экспериментальный ульцерогенез / Т. Г. Каревина, И. М. Шевчук // Патол. физиолия и эксп. терапия. - 1988. -№1. - С. 27-29.

8. Карташов С. Н. Морфофункциональная характеристика лимфатических узлов поросят при цирковирусной инфекции / С. Н. Карташов, А. М. Ермаков, А. И. Бутенков // Российский ветеринарный журнал «Сельскохозяйственные животные», 2009, №2. - С. 13-17.

9. Кочу В. М. Влияние препарата ПДЭ на антиоксидантную систему коров-рожениц / В. М. Кочу // Новые препараты в ветеринарии. - Кишинев. 1990. - C. 49-52.

10. Крыжановський Г. Н. Значение перекисного окисления липидов в патологии молодняка / Г.Н. Крыжановський // Патол. физиолия и эксп. терапия. - 2002. - №3. - С. 2-19.

11. Кудинов Р. И. Этиология, диагностика, лечение и профилактика гастроэнтеритов поросят : дисс. на соиск. уч. степени к. вет. н. : 16.00.01/ Р. И. Кудинов. - Саратов, 2003. - 112 с.

12. Кузьмич Р. Г. Перекисное окисление липидов и система антиоксидантной защиты организма животных / Р. Г. Кузьмич, Д. И. Бобрик, А. В. Саватеев. - Витебск : УО ВГАВМ, 2002. - 64 с.

13. Михайлович В. А. Проныцаемость эритроцитарных мембран и сорбционная способность эритроцитов - оптимальные критерии тяжести эндогенной интоксикации / В. А. Михайлович, В. Е. Марусанов, А. Б. Бичун // Анестезиология и реаниматология. - 1993. - №5. - С. 66-69.

14. О механизме взаимодействия АСК и индометацина с эндопероксидпростагландинсинтетазой / [Муратов В. К., Игумова Н. Д., Басевич В. В. и др.] // Фармакология и токсикология. - 1987. №5. C. 44-48.

15. Парий Б. И. Способ получения водного раствора ацетилсалициловой кислоты : авторск. свид. СССР. - 1989. - № 1489012. ДСП.

16. Паршин П. А. Клинико-морфологическая характеристика гастроентеритов поросят / П. А. Паршин, С. А. Сулейманов : материалы межд. наук.-практ. конф. - Смоленск, 1999. C. 215-219.

17. Перекисное окисление липидов и эндогенная интоксикация у животных, значение в пато- генезе внутренних болезней животных, пути коррекции / [С. С. Абрамов и др.] ; под общ. ред. С. С. Абрамова. - Витебск : УОВГАВМ. - 2007. $208 \mathrm{c}$.

18. Проченко В. А. Протекторное свойство ингибиторов ферментов протеолиза в клеточных системах при шоке / В. А. Проценко, С. И. Шпак // Нарушение механизмов регуляции и их корекция : тез. докл. IV Всес. сьезде патофизиол. Кишинев, 3-6 октября. - Т.2. - 1989. - С. 781.

19. Рябов Г. А. Окислительный стресс и эндогенная интоксикация у больных в критических состояниях / Г. А. Рябов, Ю. М. Азизов, И. Н. Пасечник // Вестн. интенсив. тер. - 2002. - №4. C. 4-7.

20. Шатохин П. П. Патогенез стрессовых язв желудка у крыс и влияние салицилатов на ульцерогенез : сборник / П. П. Шатохин, В. С. Лутан // Новые препараты в ветеринарии. - Кишинев. 1990. - C. 41-48.

21. Шатохин П. П. Противосполительные свойства водорастворимого аспирина / П. П. Шатохин // Новые препараты в ветеринари (сборник). - Кишинев, 1990. - С. 49-52.

22. Шатохін П. П. Фармакотерапевтична ефективність саліцилатів при гастроентеритах поросят : автореф. дис. на здобуття наук. ступеня к. вет. н. : 16.00.04 / П. П. Шатохін. - Харків, 1993. $25 \mathrm{c}$.

23. Bolin S. R. Postweaning multisystemic wasting syndrome induced after experimental inoculation of cesarean-derived colostrum-deprived piglets with type 2 porcine circovirus / S. R. Bolin, W. C. Stoffragen // Vet. Diagn Invest. - №13. - 2001. P. $185-194$.

24. Drabant $A$. The role of glucocozticoids in the regulation of thyropin / A. Drabant, G. Schuermeyer et al. // Acta Endocrinol - №121. - 1989. - P. 95-100.

25. Iaqer H. C. Determination of vitamin E requirement in Rats by Means of sportanrons hacmolysis in vstro / H. C. Iaqer // Nutr. Dieta. - 1968. №10. - P. 215-223.

26. Lim C-F. Drug and falty acid effects on serum thyroid hormone binding / C-F. Lim, V. Bai, D. S. Topliss // J. Clin Endocrinoe metab. - №67. - 1988. P. 682-688. 